British \& Irish Botany 2(3): 259-260, 2020

\title{
Validation of the name Cotoneaster froebelii (Rosaceae)
}

\author{
Jeanette Fryer \\ Cornhill Cottage, Honeycritch Lane, Froxfield, Hampshire, GU32 1BE, UK
}

Corresponding author: Jeanette Fryer (at postal address above)

This pdf constitutes the Version of Record published on $31^{\text {st }}$ August 2020

\begin{abstract}
The name Cotoneaster froebelii has apparently never been validly published; it is here validated as $\boldsymbol{C}$. froebelii J. Fryer, sp. nov.
\end{abstract}

\section{Introduction}

Cotoneaster froebelii is the name used for one of the more than 400 species treated in the standard monograph of the genus by Fryer \& Hylmö (2009), and one of the 90 alien taxa recognised as occurring in the wild in the British Isles (Stace, 2019). It has, however, never been validly published.

It has appeared in various lists as C. froebelii Vilm., nom. nud., in Stace (2019) as C. froebelii M. Vilm. ex Sax, and in Fryer \& Hylmö (2009) as C. froebelii Sax ex Vilmorin. "Sax" refers to a paper in the Journal of the Arnold Arboretum by Hally J. Sax (Sax, 1954). [Since the author abbreviation 'Sax' refers to Karl Sax (husband of Hally), Hally J. Sax should be abbreviated H.J. Sax]. In Sax (1954), however, the species is simply listed as $C$. froebelii Vilmorin, with no description and no reference to where Vilmorin coined the name. In any case, Vilmorin did not describe any new species of Cotoneaster, and probably, like Sax, simply listed $C$. froebelii, or possibly he simply distributed it under that name. Moreover, until the place of this listing is traced we cannot be sure which of the several Vilmorins was involved. It was probably Auguste Louis Maurice Lévêque de Vilmorin (1849-1918), to be abbreviated as M. Vilm. I therefore describe this species anew; the description is taken from Fryer \& Hylmö (2009):

\section{Cotoneaster froebelii J. Fryer, sp. nov.}

Shrub 1.5-2m; branches erect, spreading. Leaves deciduous, sometimes semievergreen, chartaceous or subcoriaceous, broadly ovate on sterile shoots, $18-28 \mathrm{x}$ $10-18 \mathrm{~mm}$, acute at apex, obtuse at base; upper surface slightly rugose, dark green, sparsely strigose, with deeply impressed veins; lower surface grey-tomentose. Fertile shoots 22-28mm, including 1-3(6)-flowered inflorescence. Hypanthium and sepals pilose-strigose, tomentose at margin; sepals acute to acuminate; petals erect, incurved, red and pink; stamens 13-20; filaments red with off-white base; anthers white. Fruit subglobose or broadly obovoid, $9-10 \mathrm{~mm}$, bright red, sparsely pilose, with calyx-lobes flat and densely pilose, with navel closed or with small opening; nutlets $(3-) 4(-5)$; style remains $1 / 2$ to $2 / 3$ from base. 
Holotype: China, N.E. Yunnan, between Yiliang and Xiaocuba, 5 October 1995, Cox \& Hutchinson 7104 (E).

If Vilmorin's listing of $C$. froebelii is traced, 'M. Vilm. ex' could be inserted before 'J. Fryer'.

Cotoneaster froebelii (Fig. 1) is a lower growing shrub than the well-known $C$. dielsianus, with a more spreading, arching habit; leaves thinner, with the upper surface dark green, sparsely strigose, and with deeply impressed veins; petioles mostly $1-2 \mathrm{~mm}$; flowering shoots up to $28 \mathrm{~mm}$ long, with 1-3(6)-flowers with mostly acute sepals; fruit 9-10mm, bright red.

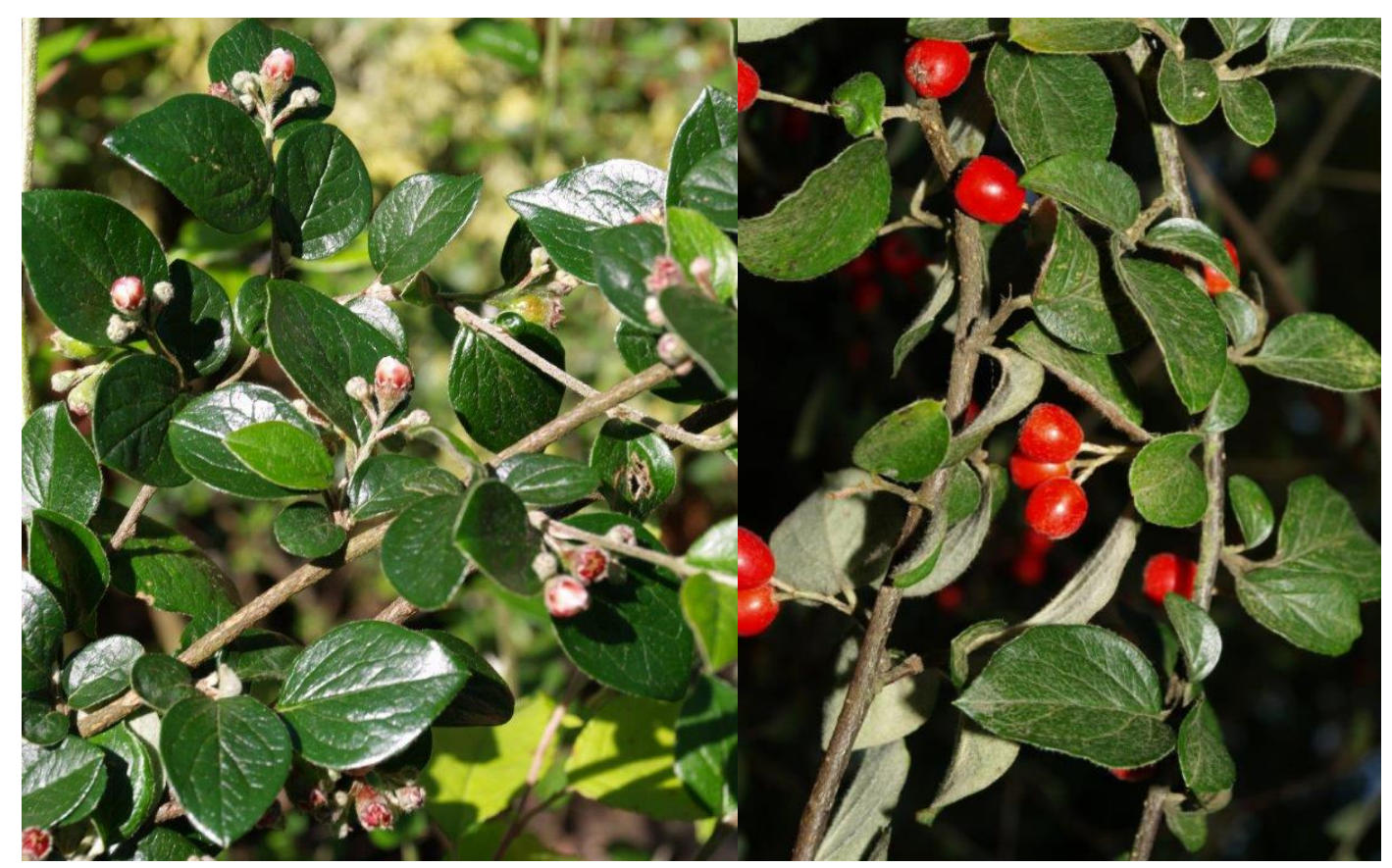

Figure 1. Flowers (left) and fruits (right) of Cotoneaster froebelii

\section{Acknowledgements}

I am grateful to Kanchi Gandhi for details of the Saxes and for nomenclatural clarifications, and to Clive Stace for assistance with the validation of the name.

\section{References}

Fryer, J \& Hylmö, B. 2009. Cotoneasters. A Comprehensive Guide to Shrubs for Flowers, Fruit and Foliage. Portland \& London: Timber Press.

Sax, H.J. 1954. Polyploidy and apomixis in Cotoneaster. Journal of the Arnold Arboretum 35: 334-365.

Stace, C.A. 2019. New Flora of the British Isles, $4^{\text {th }}$. ed. Middlewood Green, Suffolk: $C \&$ M Floristics.

Copvriaht retained by author(s). Published by BSBI under the terms of the Creative Commons Attribution 4.0 International Public License.

ISSN: $2632-4970$

https://doi.org/10.33928/bib.2020.02.259 